\title{
LEARNING WHILE HELPING: A CULTURE-BASED COOPERATIVE LEARNING MODEL FOR VOCATIONAL EDUCATION
}

\author{
Nyoman Santiyadnya ${ }^{1}$, I Made Candiasa ${ }^{2}$, Gusti Ketut Arya Sunu ${ }^{3}$ \\ Ganesha University of Education \\ Electro Education Department ${ }^{1}$, Mathematics Education Department ${ }^{2}$, Civic Education Department ${ }^{3}$ \\ Singaraja, Indonesia \\ santiyadnya@undiksha.ac.id ${ }^{1}$, arya.sunu@undiksha.ac.id ${ }^{2}$, candiasa@undiksha.ac.id ${ }^{3}$
}

\begin{abstract}
Vocational education prioritizes learning outcomes in the form of skills, so that graduates are ready to work. The applied learning model must be carefully selected in order to produce optimal skills. This research tries to develop cooperative learning model of learning while helping type adopted from culture-based learning model. The learning model has been proven capable of producing many skilled workers in various fields, carpentry, agriculture, animal husbandry, or fisheries. The results of observations and interviews show that the learning process occurs informally during the cooperative process based on the principle of interdependence. The junior worker learns while helping a more senior worker. Senior workers also learn while helping supervisors. Thus the process takes place continuously. Once a junior worker becomes a senior worker and re-recruits junior workers. While senior workers become supervisors and accompany other senior workers. The learning model can be implemented in vocational schools by preparing workshops according to the skills they want to learn. Students learn from the lowest level of skills then gradually increase to the highest level of skill. The process of tiered coaching from senior to junior occurs continuously. Teachers act as supervisors and facilitators. This learning model more guarantees the alignment of process in the learning of skills, attitudes, and behavior, so that the competencies and character of the graduates are more integrated.
\end{abstract}

Keywords-learning while helping, culture-based, vocational education

\section{INTRODUCTION}

Graduates of vocational education are expected to fill existing jobs or create job opportunities to accommodate other workers. The expansion of access to education through the development of vocational education is not expected to lead to an increase in unemployed educated workers but an increase in professionals workers in accordance with the needs of employment. The function of educational system in relation to employment includes two important dimensions: (1) quantitative dimensions which includes the functioning of the education system in supplying skilled workers in accordance with the needs of available employment, and (2) the qualitative dimension concerning its function as a producer of trained personnel who will be the driving forces of development [1]. The skills of the graduates must be in accordance with the current demands of the works that take many advantage of innovation in the field of technology. Academic ability must be able to be applied to anticipate job opportunities. All of those must be based on a superior character that reflects the character of the nation. The problem is, the learning model applied to now has not been able to produce the expected skills. Therefore, through this research developed a cultural-based cooperative learning model for vocational education, named learning while helping models.

There are two theories about education when viewed from the graduates that must be produced, namely the theory of human capital and the theory of crendalism. The theory of human capital assumes that the higher the quality of education, the higher the productivity of labor, the higher the effect on the economic growth of society [1]. People who have higher education will have more income than people who have a lower education. In essence, the theory of human capital considers education as an investment, both for individuals and for society. The investment will increase skills, and therefore also increase productivity, which will directly create welfare. The underlying assumption of the human capital theory is the free market for labor [2]. Every community has a number of jobs in high skills that bring high remuneration. The workforce that fills the job is 
determined by the education system, so that highability individuals will get the most desirable jobs.

Crendalism theorists assume that the education system should be able to open and expand the insight of the produced labor, especially in opening up new job opportunities [1]. Furthermore, it is stated that education should be able to generate manpower that is able to push the potential of society to produce products in the form of goods and services, and at the same time able to open marketing opportunities. That is, education must produce a manpower capable of expanding employment, so as not to depend on the existing employment, even otherwise able to provide employment opportunities for other workers. The theory of crendalism doubts the ability of formal education to produce skilled workers, on the contrary believes job training is a strategic medium in bridging between education with the needs of employment.

Vocational education with dual system education is a blend of the two theories above. In school, students of vocational education get productive lessons to support the skills and normative lessons to support academics. While in the industrial world students do work internships to establish skills. Thus, vocational school students get more training in skills. To date, learning models implemented in schools must be chosen wisely in order to equip learners with adequate skills. Many learning models have been developed, and many are able to provide good skills to the graduates. In addition to the optimization of skills mastery, vocational education also still requires academic education in order to develop skills later after working in the field. Furthermore, character building should be done as optimal as possible so that the graduates have good character according to the demands of the state and nation. Conditions like these require the application of learning models that can foster the competence of skills, academic competence, and character together. Indeed this is not easy, but the symbiosis between local culture-based education and modern education can produce a learning model that can integrate skills education, academic education, and character education.
Emperical data show that many skilled workers are born not through formal education. Carpenters, builders, farmers, ranchers, fishermen, even highly skilled and highly productive artists have never attended formal education. Their highlevel skills are gained from informal education while working. The model of direct involvement in work is able to deliver individuals who initially lack the skills to become skilled individuals in their field. High skills should be possessed even accompanied by good academic competence, so as to develop his skills. Character owned also tends to fit the character of the teacher who educates them.

This fact inspired the contextualization of a vocational learning model based on local culture. Contextualization is interpreted as the adoption of the local culture-based learning model which in its implementation is adapted to the present condition, in order to be able to produce the needed workforce at present. One of the learning models that was tried to be developed to be applied in vocational education is cooperative learning model of learning while helping type.

\section{METHOD}

The research wants to develop culture-based learning model for vocational education. This research consists of three stage, this is the first stage of the research that aims to explore the cultural-based learning model. The research was conducted with qualitative approach. Data were obtained from literature review, observation, and in-depth interviews with respondents. Respondents were determined by snowball technique, where the researcher asks respondents or participants to identify others to be members of sample [3]. The sample comes from community leaders and cultural-based education actors. The data were analyzed qualitatively using Miles and Huberman method [4], where the data analysis consists of three activities: data reduction, display data, and conclusion drawing or verification. 


\section{RESULT AND DISCUSSION}

The results of literature review, observations and in-depth interviews found that many of the skills that individuals acquired were not from formal education but from informal education through direct involvement. Skills in carpentry or agriculture for example are obtained from generation to generation through direct involvement in activities that can not be separated from cultural activities. Informal education through direct involvement in these areas occurs in a cooperative process between junior acting as a student and a senior who acts as a mentor under the supervision of an expert acting as a teacher. Students assist mentors while studying. Students begin to learn by helping their mentors in the job with the lowest level of skills. When there is an improvement in skills, then the student will learn while helping on a job with a higher level of skill. Thus the process takes place normaly, until at some point the student already becomes a middlelevel worker. The cooperative process for learning while helping continues until the student becomes an expert worker. Teacher who is an expert will do the monitoring while working as well.

Most learning process takes place through giving examples or instructions. While working, mentors provide examples or clues to students. Students do what is their duty by following the example or guidance of the mentor. If there is a mistake on the students, then the mentor will straighten by working directly while giving directions. If the mentor is unable to give instructions or examples, then the teacher will step in to provide an example or direction. In this context, learning occurs not only in the student itself but also in the mentor. When all goes normally, then one day the student will become a mentor, while the mentor will be a teacher or an expert.

Coaching that occurs during the collaboration process includes process and product skills. The hope, graduates are able to produce good products through good work processes as well. Products are judged by product quality measures, while process quality is judged by speed, neatness, and efficiency in material utilization. In addition to fostering skills, the collaboration process also takes place in moral or character formation, such as honesty, openness, tenacity, courtesy, and ethics. In other words, learning and evaluation of culture-based vocational education takes place in an integrated manner, whether cognitive, affective, or behavioral. Integrated assessment of cognitive and noncognitive angles can stop the inequality of treatment between individuals [5].

If the above educational model is adopted in current vocational education, then most learning process take place in the workshop. Students work while studying in the workshop accompanied by seniors as assistants under the supervision of teachers. A senior person in addition to having adequate skills should also have good character. Students help seniors while studying, while seniors help teachers while studying as well. Another advantage gained is that students, assistants, and teachers together can produce the product. The product can be used for school or community. If the product is economically valuable, then it can be marketed to help the school finance.

Objectives to be achieved through cooperative learning type learning while helping are: (1) produce graduates who have the knowledge and skills in accordance with employment; (2) produce highly disciplined graduates who have a high work ethic, full of initiative, and creative in creating new job opportunities; And (3) gain recognition and respect for work experience as part of the educational process. The achievement of the above objectives will fulfill one of the expectations of educational reform, that is to relate education to the practical world and to give more opportunities for students to compete and to be fair, both nationally and internationally.

Such vocational education can provide an understanding that formal education can produce skilled workers. Job training considered a strategic medium to bridge education with employment needs is no longer absolutely necessary. Graduates are guaranteed to have the necessary skills of the jobs, able to work in groups, have the skills to live in their social environment, and are able to share information. Such competence can be achieved because 
students experience meaningful learning through the collaboration of students, teachers, and the surrounding community in a friendly learning environment. Such learning process can lead to awareness of the students themselves to realize the learning experience on all sides.

The application of cooperative learning model type of learning by helping can be applied more optimally if vocational school is built in relevant environment. If the community is farmers, it is necessary to build a vocational school for agriculture. If the community is a fisherman, it is necessary to build a marine vocational school. The same is required to establish another vocational school. The requirement is based on the assumption that the surrounding community is an extension workshop in school. Cooperation is built between schools and partner institutions around the school. Partner institutions may be government agencies, state enterprises, private companies, cooperatives, foundations, business entities, institutions or organizations. Criteria for partner institutions include: (1) having activities and competencies relevant to the education program in the school concerned; (2) have concern and attention to the education of professionals; (3) having practicum facilities in accordance with curriculum requirements; and (4) have reliable instructors to guide student practicum.

Cooperation as above makes the students' skills more integrated. When graduated later students can devote the skills possessed in the community itself. The graduates produced are really able to move the potential of the community to produce products in the form of goods and services, and at the same time able to open marketing opportunities. They are able to expand employment, so as not to depend on the existing employment, otherwise able to provide employment opportunities for other workers. This condition at the same time is an effort of equitable development and prevent the movement of people from village to city to fight for job opportunities.

If graduates have to work for employment companies, then they are able to increase efficiency because companies no longer need to spend to do the training of labor. Complaints that the education program is not able to produce skilled labor in accordance with the needs of the labor market can be reduced. Similarly, the spotlight on weak coordination between formal education and the world of work can also be reduced. The more important thing is to prevent the increase of unemployment. It means, the expansion of learning opportunities by developing vocational school does not tend to have led to an increase in unemployed educated workers but tends to increase productive workers in accordance with employment.

One criticism of the human capital theory is to overemphasize the material dimension thus reducing the value of culture [6]. Student involvement in the surrounding environment as a workshop certainly can maintain the culture that is expected to remain owned by students. It will the phrase of Banks \& Banks [7] that everything that happens in education relating to culture, wheither in terms of recognition, transformation, or creation. The alienation that can arise from excessive use of technology can be controlled by keeping in touch with each other during the collaboration process while working. Negative influence of social media technology can be eliminated as optimally as possible because students are always under the supervision of mentors and teachers. Thus the student can still do business by sticking to the basic principles of change, that is, to take advantage of the opportunities offered and avoid negative influences, due to cultural contact and the interaction between such a wide world [8].

\section{CONCLUSION}

Cooperative learning model type learning by helping for vocational education has been tried to be developed. The learning model was adopted from cultural-based learning to teach skills in Indonesian society (especially Bali). Learning model has been applied from generations to generations for a long time. Despite the emphasis on learning skills, but the learning model also teaches knowledge, attitude and behavior simultaneously. Knowledge is related to the skills learned so that learners can develop the skills later. Attitudes and behaviors are fostered so that 
learners have good character while interacting with their social environment, either at work or in everyday life.

Learning takes place directly in the work process. Under complete conditions, during the work process involved beginner workers, intermediate workers accompanying beginner workers, and skilled supervisory workers. The beginner worker learns from the intermediate worker while working together. They both learn from the supervisor who also while working. When all the processes are run normally, upgrade of skills will take place gradually from beginner workers to intermediate workers and eventually become skilled workers. However, abnormal conditions may also occur, in which the beginner worker is forever only able to do the job with lower-level skills.

The application of cooperative learning type while learning model in vocational school needs adequate workshop. Majority learning process takes place in the workshop. Students learn to be accompanied by seniors as assistants under teacher supervision. Learning takes place while working. In addition, the vocational school is intended to be located in the relevant environment, so that the school environment can be an extension of the school workshop. To optimize student learning experience, collaboration can be established between schools and partners, such as companies, foundations, or organizations that operate involving schoolproduced skills.

\section{REFERENCES}

[1] Ace Suryadi \& H.A.R. Tilaar. 1994. Analisis Kebijakan Pendidikan, Suatu Pengantar, Bandung: Remaja Rosdakarya.

[2] Robinson, Philip. 1981. Perspektives on the Sociology of Education, An Introduction. London: Routledege \& Kegan Paul.

[3] Creswell, John W. 2008. Educational Research: Planning, Conducting, and Evaluating Quantitative and Qualitative Research. Upper Sadlle River, NJ: Pearson Education International.

[4] Miles, M.B. and Huberman, A.M. 1994. Qualitative data analysis: an expanded sourcebook. Thousand Oaks, CA: Sage Publications.

[5] Persell, Caroline Hodges. 1977. Education and Inequality. New York: The Free Press.

[6] Ace Suryadi.1999. Pendidikan, Investasi SDM, dan Pembangunan.Jakarta: Balai Pustaka.

[7] Banks, James A. \& Cherry A. Mcgee Banks. 2005. Multicultural Education: Issues and Perspectives. Danvers: John Wiley \& Sons, In.

[8] Moleong, Lexy J., et.al. 1997. Perubahan Terencana, Konsep Dasar, Teori, Proses, dan Aplikasi. Jakarta: PT. Margi Wahyu. 